\title{
Pengaruh Berbagai Perlakuan Fisik Terhadap Molekul Dan Aktivitas Protein Antibakteri Dalam Cairan Selom Cacing Tanah Perionyx Excavatus
}

\author{
Yumaihana*, Zeilly Nurachman** \\ -Jurusan Nutrisi dan Makanan Temak, Fakultas Peternakan Universitas Andalas, Padang \\ **Departemen kimia, Fakultas MIPA, ITB Bandung
}

\begin{abstract}
Earthworms are invertebrate with the unique immune system, since they are able to hold out bacterium pathogen in growing medinm. Their immune system consists of a lot of reactions including: fagocytosis, encapsulation, agglutination, opsonisation and hysis for foreign component attacked. There are some small molecules and extra cellular proteins dilute in coelomic earthworm that play an important role in immune system and antibacterial agent. The present experiment was done to study the effect of several different treatments (feeding, living. medium, electricity stimulation) on the molecules resistance and activity of anti bacterial protein in coelomic of earthworms. Coelomic dilution was extracted by using electricity stimulation at 6 volt, and the activity of anti bacterial protein was measured by spectrophotometer, and agar diffusion. Protein extra cellular molecular size in coelomic dihution was observed by Sadium Dwodecil Sulphate (SDS) electrophoresis. Results showed that the activity of anti bacterial protein in coelomic dilution, and molectule with $29 \mathrm{kDa}$ size were deleted by treatments. Extraction of coelomic dilution which contained of activity of anti bacterial protein could be done in feces from cow which was never stimulated before.
\end{abstract}

Key words : earthworm P.excavatus, SDS-electroforesis

\section{Pendahuluan}

Sistem kekebalan tubuh pada cacing tanah telah terbukti sangat kompleks, dan berbeda dari system kekebalan pada makhluk hidup tingkat tinggi seperti manusia yang memiliki sel $\mathrm{T}$ dan Tc. Kedua sel ini memiliki peranan penting dalam system imun. Tetapi, pada cacing tanah beberapa molekul kecil dan protein ekstraseluler di dalam cairan selom dapat melakukan fagositosis dan kapsulasi dalam menghancurkan bakteri pathogen yang masuk ke rongga badan (body cavity) (Cooper et al, 2002 dan Dhainaut et al, 2001).

Rongga badan adalah ruang yang memisahkan gut (saluran pencernaan) dengan organ - organ dalam. Saluran pencernaan ini memungkinkan hewan untuk mencerna makanan diluar sel (extracellular digestion). Kantung seperti gut mempunyai satu lobang pembuka dimana makanan masuk dan keluar melalui tempat yang sama. Gut lengkap mempunyai dua lobang , mulut dan anus. Gut ini kadangkadang dikatakan sebagai tabung di dalam tabung, seperti halnya pada cacing.

Hewan yang mempunyai rongga tubuh bagian dalam disebut coelomates ( selomat) dan rongganya disebut coelom ( selom ). Cairan yang terdapat di dalam selom disebut cairan selom, berfungsi untuk membantu respirasi dan sirkulasi penyebaran nutrisi, dan ekskresi cairan buangan. Cairan selom juga 
bisa menjadi tempat menyimpan telur dan sperma seperti pada ikan, memfasilitasi pertumbuhan gamet dalam tubuh hewan. Cairan ini melindungi organ dalam dan juga sebagai hidrostatik kerangka. Tetapi komposisi protein dalam cairan selom masih sangat sedikit dipelajari. Bila cacing ditusuk maka ia akan kehilangan kemampuan untuk bergerak dengan baik, karena fungsi otot tubuh tergantung pada volum cairan dalam selom. Tetapi cacing juga mempunyai kemampuan istimewa untuk meregenerasi bagian tubuh yang hilang.

Pada penelitian terdahulu telah terbukti bahwa cairan selom cacing tanah P.excavatus memiliki aktivitas antibakteri. Beberapa bakteri dari gram positif dan gram negatif telah diuji seperti Bacillus Megaterium, Pseudomonas dan lain-lain. Namun aktivitas terbaik ditunjukkan terhadap B. Megaterium. Pada Gambar 1.a. dapat kita lihat Zona bening di sekeliling kertas cakram difusi agar yang menggunakan $B$ megaterium sebagai kontrol positif. Walaupun tidak seluas yang diperlihatkan oleh ampisilin (kontrol negatif), zona bening ini sudah membuktikan suatu aktifitas antibakteri. Luas daerah bening yang sempit disebabkan oleh molekul antibakteri ini belum mumi dan kemungkinan sebagian molekul bisa menjadi sumber nutrisi untuk pertumbuhan bakteri. Secara spektroskopi bisa dilihat optikal density crude cairan selom P.excavatus (gambar 1.b). Kurva pertumbuhan $B$. megaterium dalam wadah yang mengandung cairan selom $10 \%$ berada di bawah pertumbuhan bakteri kontrol (tidak mengandung agent antibakteri apapun ). Cairan selom dapat meng-inhibisi pertumbuhan bakteri $B$, megaterium $\pm 90 \%$ dari kontrol negatif. Molekul antibakteri ini potensial sebagai agent antibakteri masa depan, tetapi perlu dilakukan penelitian lanjut terhadap kemampuan molekul dan aktifitas antibakteri ini.

a
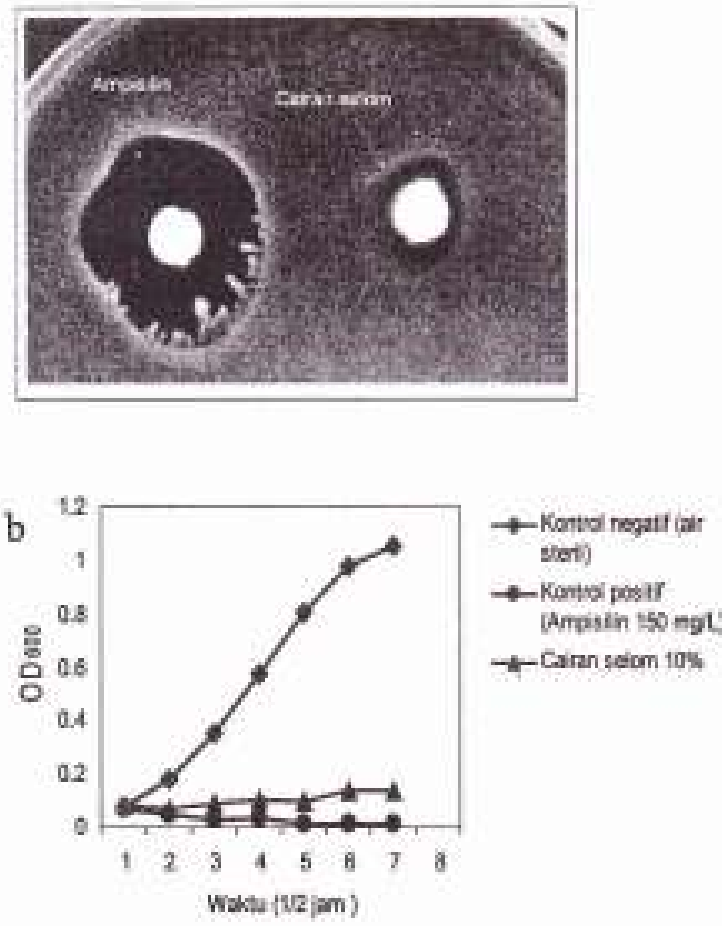

Gambar 1. Aktivitas antibakteri Cairan selom cacing tanah P.excavatus. (a).Difusi agar cairan selom dan ampisilin (kontrol) terhadap B. Megaterium. (b) Optikal density cairan selom.

Penelitian ini dilakukan untuk melihat pengaruh beberapa perlakuan fisik cacing terhadap daya tahan molekul antibakteri dan aktivitasnya. Dari penelitian ini diharapkan akan didapat kondisi yang optimum untuk mendapatkan cairan selom yang memiliki molekul antibakteri dengan aktivitas maksimum.

\section{Metode Penelitian}

Penelitian dilakukan dengan metoda eksperimen menggunakan cacing 
P.excavatus dewasa. Variasi perlakuan fisik cacing :

- Cacing diberi makan ampas tahu

- Cacing bertelur (media kotoran sapi)

- Cacing yang sudah distimulasi berkali - kali (media kotoran sapi)

- Anak dari cacing yang sudah distimulasi berkali - kali (media kotoran sapi)

- Cacing dipuasakan (direndam dalam air selama $16-18$ jam sebelum diisolai)

- Cacing segar dengan media kotoran (kontrol).

Isolasi cairan selom dilakukan dengan menstimulasi cacing tanah pada tegangan listrik $5-9$ volt. Cairan selom (kuning) selanjutnya di sentrifuga pada kecepatan $11.000 \mathrm{rpm}$ selama 10 menit agar terpisah dari cairan kental lipoprotein dan kotoran lain. Semua pengerjaan dilakukan pada $4^{\circ} \mathrm{C}$. Cairan crude selom diuji aktivitas antibakteri terhadap $B$. megaterium secara spektrofotometri. Kandungan protein diukur dengan metode Lowry dan selanjutnya dilihat ukuran molekul protein ekstraselular yang dikandung cairan selom secara SDS-PAGE.

\section{Hasil dan Pembahasan}

\section{Perlakuan fisik}

Setiap gram cacing dapat menghasilkan $\pm 40,73 \mu \mathrm{L}$. Dari beberapa variasi perlakuan dapat diamati perbedaan pada aktivitas cairan selom. Cacing yang diberi makan ampas tahu tidak menunjukan aktivitas antibakteri terhadap $B$. megaterium. Hal ini diduga disebabkan oleh media yang cukup bersih dari kuman sehingga tidak merangsang cacing untuk menghasilkan cairan antibakteri. Penggunaan ampas tahu cukup baik untuk meningkatkan volume biomassa tetapi tidak kandungan molekul antibakterinya. Cacing yang sedang mengandung cocon, maupun yang baru mengeluarkan cocon disiapkan untuk uji aktivitas antibakteri. Dari hasil uji optikal densiti ternyata cairan selomnya tidak menunjukan aktivitas antibakteri terhadap B. megaterium. Cairan selom malah menjadi nutrisi bagi bakteri. Hal ini terlihat dari aktivitas bakteri yang berada di atas kontrol (Gambar 2.a). Fenomena ini menunjukan adanya protein dalam cairan selom yang dapat meningkatkan aktivitas $B$. megaterium sehingga terjadi produksi sel dengan cepat. Pertumbuhan bakteri ini terlihat dari uji kualitatif pada Gambar 2.b. $\mathrm{Hal}$ yang sama ditunjukan oleh cairan selom yang berasal dari cacing yang sudah distimulasi berkali-kali, anak cacing yang pernah distimulasi.

Cacing dipuasakan $16-18$ jam, memberikan volume selom yang lebih banyak dan aktivitas antibakteri sama bagusnya dengan cacing yang tidak dipuasakan (Gambar 3) tetapi sebagian cacing mengalami stress yang terlalu kuat sehingga mati saat distimulasi. Mempuasakan cacing dan mencucinya dimaksudkan untuk menghilangkan atau meminimumkan kontaminan. Cara lain yang dilakukan untuk memperkecil kontaminan adalah Dialisis cairan selom crude. Cara ini menghasilkan aktifitas antibakteri yang sama dengan cacing yang dipuasakan.

a)

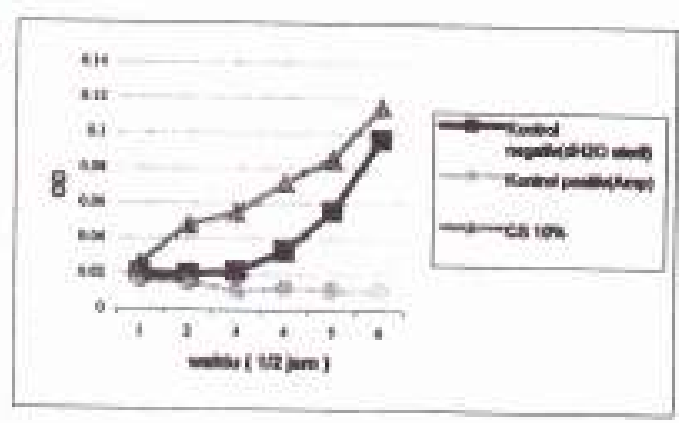

ISSN: $1907-1760$ 
b)

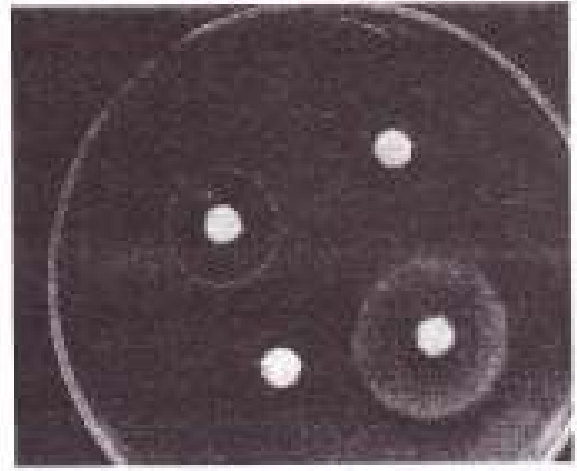

Gambar 2. Cairan selom (CS) tidak memiliki aktivitas antibakteri. (a) Uji kuantitaif menunjukan aktivitas cairan selom yang diberi makan ampas tahu, berada di atas kontrol. (b) $\mathrm{Uji}$ kualitatif cairan selom (1) Ampisilin $150 \mu \mathrm{g} / \mathrm{ml}$ (2) CS dari keturunan cacing yang pernah distimulasi (3) CS dari cacing yang distimulasi berkali-kali (4) CS dari cacing makan tahu. Inhibisi pertumbuhan balkteri ditunjukan oleh ampisilin, dengan zona bening yang lebar. Pada tiga sampel yang lain, disekitar kertas cakram bakteri tumbuh lebih subur.

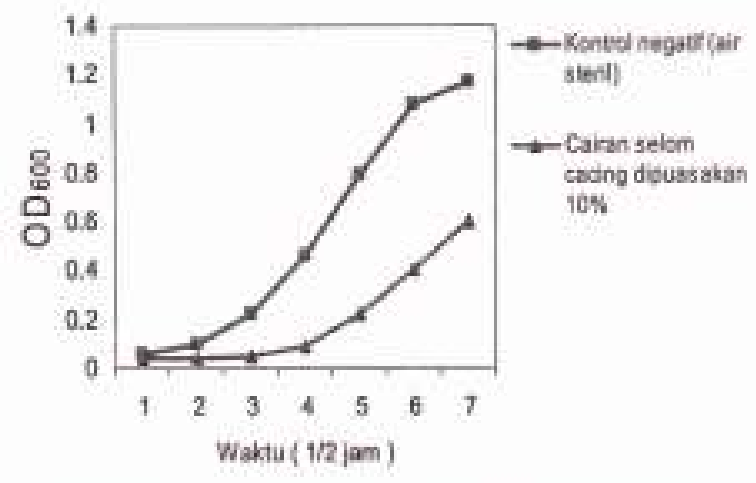

Gambar 3. Kurva pertumbuhan B. megaterium dalam media yang mengandung $10 \%$ Cairan Selom dari cacing yang di puasakan 1618 jam.

Isolasi sebaiknya dilakukan satu kali untuk setiap cacing, jangan dilakukan berulang kali sekalipun cacing yang sudah distimulasi akan segar kembali setelah satu hari dimedianya. Cacing yang berulang kali distimulasi akan mengalami perubahan bentuk klitelium (membengkak) dan warna kulit tidak mengkilat lagi sebagai pertanda cacing tidak sehat disamping ciri ciri lain yaitu gerak cacing menjadi lamban.

Perubahan ini dipengaruhi oleh cairan tubuhnya yang sudah diekstrak, karena aktivitas cacing dan kerja otot tergantung volume cairan selom yang ada dalam rongga selom. Tubuh cacing yang sudah distimulasi kembali memproduksi cairan selom, tetapi cairan ini tidak lagi memiliki aktivitas anti bakteri. Diduga ada perubahan yang terjadi dalam metabolisme tubuh cacing bahkan lebih jauh mungkin ada mutasi yang terjadi diuntan asam nukleatnya. Ini diperkuat oleh fakta bahwa kokon yang dihasilkan akan mengeluarkan anak yang juga tidak memiliki aktivitas anti bakteri terhadap $B$. megaterium. Sekalipun berada dalam $100 \%$ kotoran ternak yang mengandung bermacam - macam mikroorganisme, kondisi ini tidak mampu menstimulasi cacing untuk mensekresikan molekul - molekul litik yang berperan dalam aktivitas antimikroba. Cacing tanah tetap bertahan hidup dalam lingkungan ekstrim karena sistem kekebalan tubuh cacing sangat kompleks. Selain molekul litik, aktivitas antibakteri cacing tanah masih memiliki leukosit dan klorogosit yang bisa membunuh sel asing yang masuk ke tubuh saat cacing makan. Kontaminan jenis tertentu bisa menjadi inhibitor bagi salah satu protein dan sebaliknya bisa menjadi pemicu untuk menaikkan aktivitas antibakteri protein jenis lain. 
Melalui percobaan lanjut menggunakan kromatografi penukar anion, kolom HiPrep 16/10 sepharosa, telah terbukti bahwa ada fraksi (ditunjukkan dengan puncak tajam) pada kromatogram yang merupakan molekul dengan ukuran kecil (data tidak ditampilkan) dan memiliki aktivitas antibakteri. Fraksi kromatografi molekul kecil ini belum diidentifikasi ukuran molekul dan jenisnya, tetapi dari uji difusi agar dapat dilihat zona bening yang menyatakan aktivitas antiB.megaterium (Gambar 4). Luas zona bening yang cukup lebar menandakan kuat aktivitas antibakteri cukup tajam.

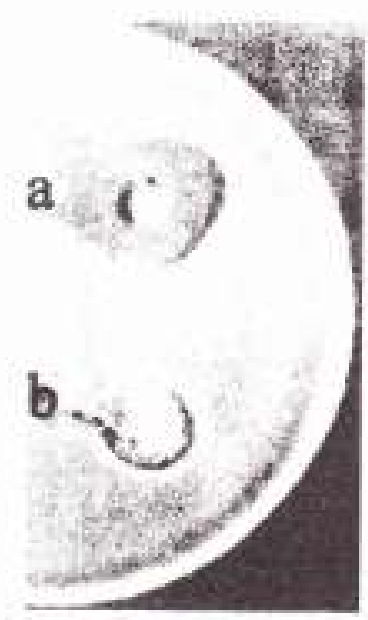

Gambar 4. Uji kualitatif eairan seiom aktif antibakteri. (a) Ampisilin (b) fraksi Kromatografi penukar anion

\section{Kadar protein}

Molekul antibakteri pada cacing tanah merupakan suatu protein ekstraselular yang dihasillkan sebagai molekul untuk kekebalan tubuh. Kadar protein dalam cairan selom diuji secara Lowry dengan menggunakan kurva standar dari protein BSA yang memiliki nilai $\mathrm{R}^{2}=$ 0,996 dan $Y=0,0007 X+0,0067$. Dari plot gambar kurva standar dan perhitungan, didapat kadar protein antibakteri dalam cairan selom adalah $22,475 \mathrm{mg} / \mathrm{mL}$.

\section{Elektroforesis}

Kondisi lingkungan sangat mempengaruhi cacing dan mutu cairan selom yang diproduksinya. Dari beberapa variabel yang telah dilakukan, karakter protein cairan selom ekstrak kasar dan hasil dialisis diidentifikasi dengan elektroforesis (Gamber 5)

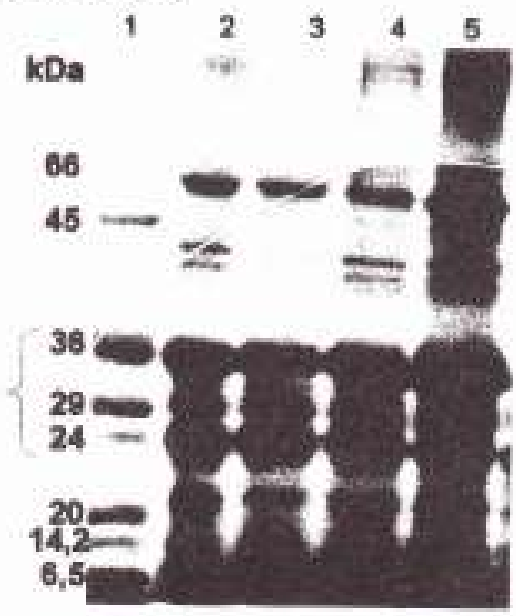

Gambar 5. Profil SDS-PAGE pita protein dalam cairan selom. Lajur 1. protein penanda, 2. dialisat cairan selom dari cacing dipuasakan, 3. dialisat cainan selom dari eacing segar, (4) cairan selom dari cacing dipuasakan, dan 5, cairan selom dari cacing segar. Protein penanda (kDa): albumin serum sapi (66), Ovalbumin telur ayam (45), gliseraldehid-3-fosfat dehidrogenase otot kelinci (36), karbonat anhidrase sel darah merah sapi (29), tripsinogen pankreas sapi (24), inhibitor tripsin kacang kedelai (20), alaktsalbumin susu sapi $(14,2)$, aprotini dari paru-paru sapi $(6,5)$.

Cairan selom yang diisolasi dari cacing segar dan cacing dipuasakan sama - sama memiliki aktivitas antibakteri. Karakter pita protein yang teridentifikasi sama, memiliki pita 
dominan pada bobot molekul 36,29 dan $24 \mathrm{kDa}$. Perlakuan dialisis yang menghasilkan kurva pertumbuhan sama dengan cairan selom dari cacing dipuasakan, diperkuat oleh tampilan pita molekul protein dengan ukuran yang sama pada Gambar 5, lajur 2 dan 4. Artinya sebagian sisa metabolit telah dikeluarkan dari tubuh cacing selama proses perendaman. Dialisis juga tidak menyebabkan protein cairan selom dari cacing yang dipuasa terdegradasi (Gambar 5. lajur 2), Cara dialisis perlu dipertimbangkan untuk pengembangan teknik isolasi cairan selom.

Sedangkan pada cairan selom dari cacing segar, dialisis menyebabkan munculnya dua pita baru dengan bobot molekul disekira $45 \mathrm{kDa}$, dan antara 29 dan $36 \mathrm{kDa}$. Berkemungkinan ada protein sekira $65 \mathrm{kDa}$ yang terdegradasi (Gambar 5 lajur 3). Perlakuan dialisis tidak hanya mengurangi metabolit kecil tetapi dapat juga mengurangi aktivitas antibakteri dalam cairan selom. Munculnya pita baru tidak mempengaruhi aktivitas secara langsung, karena pita yang diperkirakan terdegradasi tidak memiliki aktivitas antibakteri melalui pengujian kualitatif. Berkurangnya aktivitas antibakteri lebih disebabkan oleh terlarutnya protein ke medium dialisis.

Melihat karakter pita protein pada cairan selom yang tidak aktif, ada perbedaan pita yang muncul (Gambar 6). Dari tiga varian cairan selom tidak aktif, ketiganya tidak memiliki pita protein $29 \mathrm{kDa}$. Hilangnya protein ini menyebabkan tidak adanya aktivitas antibakteri bahkan protein menjadi nutrisi bagi $B$. megaterium. Stimulasi pada cacing dengan tegangan 9 volt diduga terlalu ekstrim bagi kekebalan tubuh cacing sehingga ada yang berubah dalam sistem tubuhnya dan sifat ini diturunkan ke anak. Hal ini didukung oleh sistem kekebalan tubuh jenis bawaan yang bersifat diturunkan dari orang tua.

Cairan selom yang tidak aktif, berkemungkinan masih mengandung protein lain yang juga mempunyai sifat antibakteri tetapi belum diaktifkan. Praduga ini muncul dari pengujian aktivitas antibakteri terhadap cairan selom yang tidak aktif pada gambar 5 lajur 4 dan 2 , setelah 14 dan 8 hari berturut - turut disimpan pada $-20^{\circ} \mathrm{C}$. Dari uji aktivitas dengan difusi agar didapatkan hasil seperti terlihat pada gambar 7 dan 8 . Sifat antibakteri yang muncul bukan dari protein yang diamati, tetapi berkemungkinan dari fungsi molekul lain dalam sistem kekebalan cacing tanah.

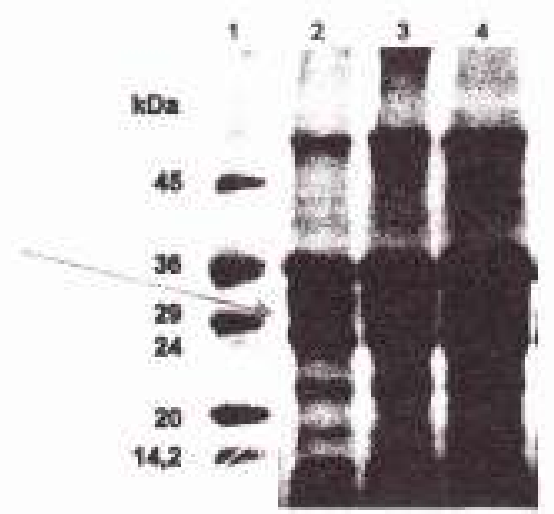

Gambar 6. Profil SDS-PAGE pita protein dalam cairan selom yang tidak aktif. Lajur 1. protein penanda, 2. cairan selom dari eacing ber-telur, 3. cairan selom dari eacing yang diberi palcan am-pas tahu, dan 4. cairan selom dari keturunan eacing yang perash disetrum.

Analisis ini diperkuat oleh hasil eksperimen di lapangan bahwa cacing yang secara kualitatif cairan selomnya tidak memiliki aktivitas antibakteri, tetapi dapat hidup subur dalam media 
yang patogen. Penelitian Field et al., (2004) tentang prophenoloxsidase (ProPO) cascade seakan memberikan gambaran dari sebuah pengamatan.

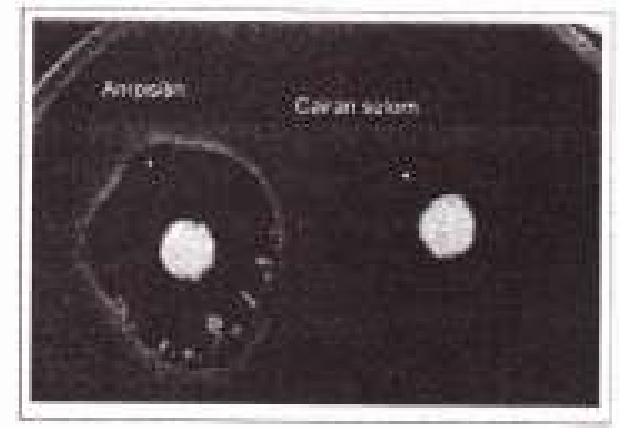

Gambar 7. Uji kualitatif cairan selom pada gambar 5. lajur 4. Hari ke 14 penyimpanan pada $20^{\circ} \mathrm{C}$. Zona inhibisi terlihat disekitar kertas cakram, menunjukan adanya aktivitas antibakteri.

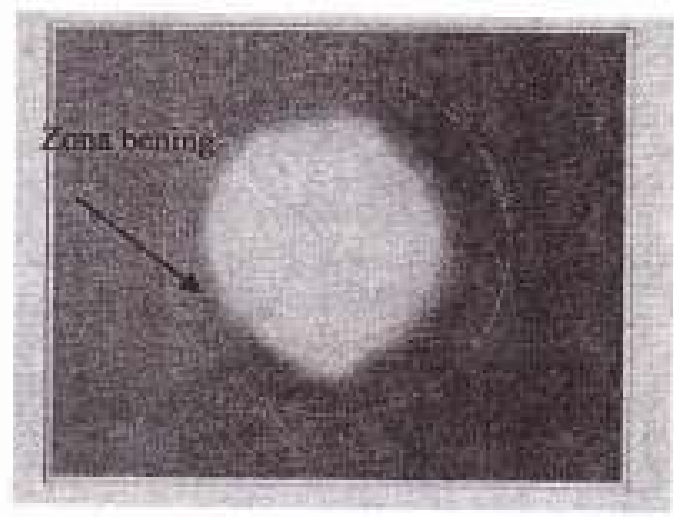

Gambar 8. Uji kualitatif cairan selom pada gambar 5 lajur 2. Hari ke 8 penyimpanan pada $-20^{\circ} \mathrm{C}$. Zina inhibisi terlihat disekitar kertas cakram.

Profenoloksidase adalah contoh molekul litik yang ditemukan dalam sistem kekebalan tubuh cacing tanah. Proenzim ini menjadi aktif setelah dirangsang oleh $\beta-1,3$-glukan dan lipopolisakarida. Secara teoritis sebuah molekul proenzim membutuhkan waktu satu sampai dua minggu untuk menjadi aktif.

\section{Kesimpulan}

Dari penelitian ini dapat disimpulkan bahwa

- Beberapa perlakuan fisik, bisa menghilangkan aktivitas antibakteri pada molekul protein ekstraselular cairan selom. Perlakuan ini juga mempengaruhi daya tahan molekul protein sehingga mengalami degradasi menjadi molekul yang lebih kecil.

- isolasi yang menghasilkan cairan selom aktiv-antibakteri adalah cairan selom dari stimulasi cacing segar (belum pernah distimulasi) yang hidup dimedia kotoran ternak (sapi).

\section{Ucapan terimakasih}

Semua analisa dilakukan dilaboratorium biokimia ITB. Terimakasih atas semua kemudahan dan bantuan fasilitas yang diberikan.

\section{Daftar Pustaka}

Anderson, R.S., (1988), Bacteriostatic faktor(s) in the coelomic fluid of Lumbricus terrestris, Dev. Comp. Immun, 12, 189-194.

Bauer, A.W., Kirby, W.M.M., Sherris, J.C., Turck, M., (1966) Antibiotic susceptibility testing by standardized single disk method, Am. J. Clin. Pathol., 45, 493-496.

Cassell, G.H., and Mekalanos, (2001), Development of antimicrobial agents in the era of new and reemerging infectious infectious. deseases and increasing antibitic resistance., JAMA, 285, 601-605.

Chauduri, P.S., and Bhattacharjee, G., (2002), Capacity of various experimental diets to support biomass and reproduction of Perionyx excavatus, Bioresource Technol, 82(2), 147-150. 
Cooper, E.L., and Roch, P., (2003), Earthworm immunity : a model of immune competence, Pedobiologia, 47.

Cooper, E.L., Kauschke, E., and Cossarizza, A, (2002), Digging for innate immunity since Darwin and Metchnikoff, Bioassays, 24(4), 319-333.

Dhainaut, A., Scaps, P., (2001), Immune defense and biological responses induced by toxics in annelida, Can. J. Zoo./Ref. Can. Zoo., 79(2), 233253.

Edwar, C.A., Dominguez, J., Neunauser, E.F., (1998), Growth and reproduction of Peronyx excavatus (Perr.) (Megascolecidae) as factor in organic waste management, Biol. Fertil Soil, 27, 155-161.

Eue, L, Kauschke, E, Mohrig, W, and Cooper, E.L., (1998), Isolation and characterization of earthworm hemolysins and aglutinins, Dev. Comp. Immun., 22 (1), 13-25.

Hanusova, R., Tuckova, L., Halads, P., Bezouska, K., (1999), Peptide fragments induce a more rapid immune response than intact protein in earthworms, Dev. Comp. Immun., 23, 113-121.

Heitz, F., Mau, N.V., (2002), Protein structural changes induced by their uptake at interfaces, Biochem. Biophys. Acta, 1597, 1-11.

Hirigoyenberry, F., Lassalle, F., and Lassegues, M. (1990),
Antibacterial activity of Eisenia ferida andrei coelomic fluid : Transcription and translation regulation of lysozyme and proteins evidenced after bacterial infection, Comp. Biochem. Physiol, 95B(1), 71-75.

Lange, S., Kauschke, E., Mohrig. W., and Cooper, E.L., (1999), Biochemical charcteristics of Eiseniapore, a pore-forming protein in the colelomic fluids of earthworms, $J$. Biochem, 262, 547-556.

Milochau, A., Lassgues, M., Valembois, P., (1997), Purification, characterization and activities of two hemolytic and antibacterial proteins from coelomic fluids of the annelid Eisenia fetida andrei. Biochem. Biophys. Acta, 1337, 123-132.

Pan, W., Liu, X., Ge, F., and Zheng. T., (2003), Reconfirmation of antimicrobial activity in the coelomic fluids of the earthworm Eisenia ferida andrei by colorimetric assay, $J$. Biosci, 28, 723-731.

Roch, P., Lassegues, M., and Valembois, P., (1991), Antibacterial activity of Eisenia fetida andrei coelomic fluid : III-relationship within the polymorphic hemolysins, Dev. Comp. Immun., 15, 27-32.

Yumaihana, (2005), Identifikasi Protein Anti Bacillus mageterium dalm Cairan selom Cacing Tanah Periony excavatus, Thesis, ITB

Alamat korespondensi : Yumaihans, S.Si, M.Si

Jurusan Nutrisi dan Makanan Ternak

Fakultas Peternakan Universitas Andalas

Padang

Diterima: 28 Agustus 2007, Disetufui: 24 September 2007 